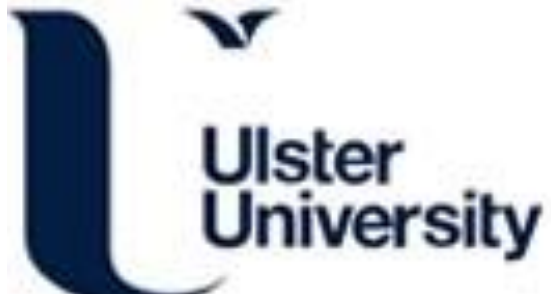

\section{Using the resource-based view in multinational enterprise research}

Beamish, P. W., \& Chakravarty, D. (2021). Using the resource-based view in multinational enterprise research. Journal of Management, 47(7), 1861-1877. https://doi.org/10.1177/0149206321995575

Link to publication record in Ulster University Research Portal

\section{Published in:}

Journal of Management

Publication Status:

Published (in print/issue): 01/09/2021

DOI:

$10.1177 / 0149206321995575$

\section{Document Version}

Author Accepted version

\section{General rights}

Copyright for the publications made accessible via Ulster University's Research Portal is retained by the author(s) and / or other copyright owners and it is a condition of accessing these publications that users recognise and abide by the legal requirements associated with these rights.

\section{Take down policy}

The Research Portal is Ulster University's institutional repository that provides access to Ulster's research outputs. Every effort has been made to ensure that content in the Research Portal does not infringe any person's rights, or applicable UK laws. If you discover content in the Research Portal that you believe breaches copyright or violates any law, please contact pure-support@ulster.ac.uk. 


\title{
Using the resource-based view in multinational enterprise research
}

\begin{abstract}
The resource-based view (RBV) has evolved into a pre-eminent theory of strategic management. It is widely used by IB scholars, since there is considerable synergy in core research questions pursued by international business (IB) and strategy researchers. However, in research on multinational enterprise (MNE) behavior, the use of RBV remains limited, relative to other influential perspectives such as the eclectic paradigm, the Uppsala model, and institutional theory. This is not surprising since the RBV was developed to explain performance differentials between country-centric firms with dominant product businesses, rather than large MNEs with an expansive product-geographic scope. We describe how these limitations arise from the wider range of outcomes and explanatory variables, multiple levels of analysis, and the spatial, economic, and institutional barriers that are relevant to MNEs. We discuss the application of RBV to MNE research by the first author and other IB scholars. We then provide directions on how future research could use RBV more fruitfully to examine MNE performance and sources of competitive advantage in several areas. These include diversified corporations, subsidiary agglomeration, emerging market MNE internationalization, subsidiary autonomy, international joint ventures and alliances, and corporate social responsibility. Drawing upon teaching case examples from the first author's work, we also point to the effectiveness of RBV in teaching with business cases, given its focus on firm performance (strategy).
\end{abstract}

Keywords: Resource-based view, multinational enterprises, strategy, international business, limitations, future research, teaching cases 
The resource-based view (Barney, 1991) seeks to understand the sources of firm-level sustained competitive advantage (SCA) and builds upon the earlier contributions of Penrose (1959), Wernerfelt (1984), Dierickx \& Cool (1989), and Prahalad \& Hamel (1990). It explains how heterogeneity (i.e., value, rarity) and immobility (i.e., inimitability) or VRI in firm-specific resources and capabilities lead to SCA. A critical additional theoretical development recognized that besides VRI, a firm also needed to be well-organized (e.g., structure, control systems, incentives) to exploit the full potential of such resources and capabilities for competitive advantage (Barney, 1997; Barney \& Mackey, 2005). Consequently, RBV's widespread use (primarily in strategic management research, but also in connected disciplines), prominent spin-off perspectives, and meta-analyses of the empirical evidence suggest that it has evolved into a preeminent theory of strategic management (Barney, Ketchen, \& Wright, 2011).

As noted by Peng (2001), there is considerable synergy in core research questions pursued by international business (IB) and strategy researchers. Understanding the sources of competitive advantage is integral to IB decisions and outcomes. Multinational enterprise (MNE) resource and capability advantages are critical to foreign direct investment (FDI) (Dunning, 1995); and according to Rumelt, Schendel, and Teece (1994) "What determines the international success and failure of firms" (p. 564) is a fundamental strategy question. Nevertheless, in research on MNE behavior, which is my ${ }^{1}$ focus, the use of RBV is more limited, relative to the use of other influential perspectives such as the eclectic paradigm, the Uppsala model, and institutional theory. From an IB research standpoint, while 14\% of articles published since 1991 in the Journal of International Business Studies (JIBS) cite Jay Barney (for comparison, 21\% cite Michael Porter), the absolute numbers are trending down in the most recent decade (78) versus the previous decade (92).

\footnotetext{
${ }^{1}$ Use of "my" or "I" in this article refers to the first author (Paul Beamish).
} 
In the remainder of this article, we explain limitations in applying RBV to MNE research, discuss where I have used RBV, where it has been used effectively by other IB scholars, and provide directions on how RBV could be used more fruitfully in MNE research.

\section{Limitations to the Use of RBV in MNE research}

IB scholars have long recognized that MNEs possess distinctive capabilities. These are commonly understood as firm-specific (ownership) advantages (FSAs) e.g., differentiated products, management skills, reputed brands, that give them a relative competitive advantage over domestic firms (e.g., Hymer, 1976; Rugman, 1981). While ownership advantages are necessary, they are insufficient to explain MNE strategic decisions and outcomes related to FDI. Competing in overseas markets requires MNEs to consider foreign location-specific constraints (and benefits) that may help or hinder the transferability of ownership advantages. Internalizing operations via wholly owned foreign subsidiaries must be weighed against the efficiency, profitability, and risks of other options such as exporting, licensing, or joint ventures with local partners (Beamish \& Lupton, 2009; Hennart, 2009). For instance, consider a host location with favorable demand conditions that has a weak regulatory environment, and is culturally distant from an MNE's home location. To successfully operate there, an MNE may need to consider marketing/distribution joint ventures with local firms to overcome cultural barriers and better access the consumer market, while exercising sufficient control to protect its intellectual property.

Thus, explaining FDI rationale, location choice, and performance outcomes, requires an inter-dependent consideration of firm-specific (ownership) advantages, location-specific advantages/challenges, and entry mode (internalization). Given the need for this comprehensive 
explanatory perspective, Dunning's OLI (i.e., ownership ${ }^{2}$, location, and internalization theory of the MNE) a.k.a. the "eclectic paradigm" transcends all others by integrating multiple theoretical streams across firm and location levels to explain FDI (Eden \& Dai, 2010; Rugman, Verbeke, \& Nguyen, 2011). Most theories are developed with a particular type of business in mind and the eclectic paradigm was conceived for MNEs. Its evolution into a broad tent is consistent with the diverse nature of MNE operations and decision making considerations e.g., international production, location-specific advantages, and institutional quality (Dunning, 1988; Dunning, 1998; Dunning \& Lundan, 2008). In contrast, the RBV was developed for product-focused country-centric organizations. Its evolution has involved understanding resource/capability inimitability/non-substitutability (e.g., Dierickx \& Cool, 1989; Peteraf \& Barney, 1983) the knowledge-based view (Grant, 1996), and dynamic capabilities (Teece, Pisano \& Shuen, 1997), which while important, are not as frequently studied within the MNE context.

Given the above, it is not surprising that while a Scopus search for JIBS articles citing Jay Barney since 1991 retrieved an impressive 188 articles (14\% out of a total of 1,385 JIBS publications ${ }^{3}$ ), a corresponding search for articles citing John Dunning located 2.4x that number i.e., 445 articles ( $32 \%$ of total). For perspective, Table 1 lists the 10 most cited authors in JIBS since 1991 (Dunning is \#3). Over the same timeframe, seven of my JIBS publications have cited Dunning, while only one has cited Barney (Dai, Eden, \& Beamish, 2013).

$$
\text { *** Insert Table } 1 \text { about here } * * *
$$

\footnotetext{
${ }^{2}$ Note that the "O" in Dunning's OLI includes tangible and intangible assets (e.g., human resources, patents) as well as an MNE's organizing capabilities to co-ordinate and effectively exploit its network of geographically dispersed operations and assets (Eden \& Dai, 2010). This latter aspect is analogous to the "O" in the RBV's VRIO model.

${ }^{3}$ Search excluded JIBS editorials and was conducted from 1991 to September 21, 2020.
} 


\section{Phenomena and Explanatory Variables}

RBV is a theory of sustained competitive advantage, hence empirical studies that use RBV to frame their theoretical arguments and/or test RBV (see Newbert, 2007 for a review), attempt to explain differences in inter-firm performance over time (DV) based on differences in resource/capability endowments (IV). MNE and foreign subsidiary performance/survival is an important DV in IB research, (especially my research). However, much IB research entails explaining foreign location choices and entry modes that best position an MNE to exploit its ownership advantages, rather than focusing solely on the relationship between ownership advantages and performance. Hence, RBV as a theoretical lens is less appropriate for these studies. Relatedly, considerable IB research also involves the empirical relationship between location choice/entry mode and foreign affiliate (subsidiary) performance, wherein firm-level resource/capability endowments (e.g., technological capability, MNE size) are used as control variables. Here again, the use of RBV becomes less pertinent.

Our thinking here is depicted in Figure 1, which refers to antecedents and performance consequences of MNE location choice. The majority of IB empirical research examines the relationships between foreign location-specific attributes (A), MNE (firm-level) characteristics (B1), subsidiary (affiliate-level) characteristics (B2), and foreign location choice decision (C) (Kim \& Aguilera, 2016; Nielsen, Asmussen, \& Weatherall, 2017). This is where and why theories/perspectives such as the eclectic paradigm, internalization, transaction cost economics, institutional theory, and the Uppsala model are widely used in IB research. Of course a considerable body of IB research also examines MNE and foreign subsidiary performance (D) (based on $\mathrm{A}, \mathrm{B} 1, \mathrm{~B} 2$, and $\mathrm{C}$ ). In our opinion, RBV is mostly useful in IB in examining the relationship between B1 (and to a lesser extent B2) and performance (D). 
*** Insert Figure 1 about here ***

My eight journal publications that explicitly use RBV (and its core propositions) as a central theoretical lens serve to illustrate the points above (For perspective, these are eight ${ }^{4}$ $\mathrm{RBV} / \mathrm{RBT}$ based papers out of a total of $110+$ journal publications during this period). Of these eight, three assess the effect of firm-level capabilities on firm-level performance. Lee, Beamish, Lee, and Park (2009), and Dhanaraj and Beamish (2003) account for the effect of capabilities such as $R \& D$, firm size, and domestic market position on the export performance of North American small and medium firms, and Korean manufacturers respectively. Fang, Wade, Delios, and Beamish (2007) investigate the impact of MNE-level knowledge resources (international and host country experience; and technology and marketing know-how) on foreign subsidiary profitability. Three others examine the impact of firm-level capabilities on international joint venture (JV) performance. Ainuddin, Beamish, Hulland, and Rouse, (2007) and Choi and Beamish (2013) focus on complementary capabilities between foreign partners (e.g., technical expertise, product reputation) and local partners (e.g., local knowledge, marketing networks). Lu and Beamish (2006) explore how host country knowledge and size-based partner resources can help small and medium enterprises overcome liabilities of foreignness, newness, and smallness. The remaining two focus on the relationship between foreign subsidiary resources and corresponding performance. Jiang, Beamish, and Makino (2014) suggest that rapid host country subsidiary expansion may negatively impact the process of accumulating valuable intangible assets; and Dai, Eden, and Beamish, (2017) suggest that superior resources which normally form the basis for value creation can expose firms and their subsidiaries to risks in conflict zones. Thus six of these eight papers consider the

\footnotetext{
${ }^{4}$ Note that while 25 of my journal articles to date cite Barney (1991), such citations do not necessarily mean that RBV is central to the paper's theoretical arguments and/or empirical scope.
} 
relationship between firm-level (MNE) capabilities (B1) and performance (D) and two study the link between subsidiary-level resources (B2) and performance (D).

Use of RBV in my work often requires integrating additional theoretical perspectives to account for multiple levels of analysis and/or foreign location context. For instance, Lu and Beamish (2006) combine the resource-based view with institutional theory to explain economic and social drivers that affect longevity and profitability of SME IJVs; Jiang et al. (2014) supplement RBV with the Uppsala model to explain why MNE subsidiaries require time to develop knowledge of and experience in unfamiliar markets; and Dai et al., (2017) integrate the resource-based view with real options theory to explain why some MNEs stay, while others exit conflict zones. I explain below why RBV has limited relevance when multiple levels of analysis (parent MNE and foreign subsidiary) and location attributes such as economic and institutional environments, need to be considered as is most often the case with (my) IB empirical research. Over the years, and especially in the last decade, the focus of my research has shifted from the MNE (parent) level to the affiliate (foreign-subsidiary) level. Correspondingly, I have relied less on RBV and more on the eclectic paradigm. Figure 2 shows the contrast over time in my cumulative journal publications that have cited Barney vs. Dunning, indicating relative divergence in numbers since the year 2012. Given research development and publication timeframes, I believe a critical inflection point entailed Dunning and Lundan's (2008) article which recognized the importance of institutional factors in shaping antecedents and outcomes of MNE activity, and incorporated them into the OLI paradigm.

*** Insert Figure 2 about here $* * *$ 


\section{Level of Analysis}

It is very difficult to get specific about corporate strategy for large, diversified MNEs (e.g., Sony, Tata, Samsung). Even for arguably less diversified MNEs such as Toyota, it is important to understand that it has 17 major group companies (across a range of industry sectors e.g., automobiles, construction, textiles) with 717 subsidiaries. For such firms, there is a need to disaggregate to identify meaningful cause and effect relationships (e.g., business units explain the greatest amount of variance in corporate profitability whereas corporate effects are negligible (Rumelt, 1991)). Hence most other IB scholars, including myself, have increasingly shifted their unit of analysis and measurement from the corporate level to the foreign subsidiary (Rugman et al., 2011). Since RBV is oriented towards the firm-level, rather than the subsidiary, it is most relevant for an undiversified firm. The VRIO framework applies largely to single product or dominant business firms where for instance, innovation capability can be linked with corporate level R\&D spend and competitive advantage outcomes e.g., number of patents.

Relatedly, developing capabilities for SCA requires integration and fit across the valuechain. For instance, managerial skills, recruitment and retention processes, R\&D strengths, supplier partnerships, marketing knowledge, and production technology, must be closely integrated for successful innovation. This again suggests that the appropriate organizational level for RBV is a focused product firm or a specific product division within a diversified firm. The point is that since an MNE's value-chain is typically disaggregated across its geographical network, often with significant reliance on external firms (Mudambi \& Puck, 2016), it is rare for any foreign subsidiary to encompass a value-chain that can be assessed in terms of VRIO and competitive advantage. Hence, as I have increasingly focused on foreign subsidiary-level research over the last two decades, my use of RBV has diminished. For perspective, I have published 54 
papers on subsidiary level phenomena and only the aforementioned two (Dai et al., 2017; Jiang et al., 2014) explicitly utilize RBV in examining the performance impact of subsidiary-level resources and capabilities.

\section{Liabilities of Foreignness and Incremental Learning}

IB scholars have long recognized the influence of formal and informal institutions such as laws, regulations, rules; and norms, ethics, and cultures (North, 1991; Scott, 2008) on MNE FDI decisions. Reducing "liabilities of foreignness" (LOFs) arising from geographical distance and/or unfamiliar economic, institutional, and cultural environments to an MNE's home country is critical to foreign subsidiary location choice and entry mode (Gaur, Delios, \& Singh, 2007; Hymer, 1976; Zaheer, 1995). On a related note, MNE experience and learning, adaptation, and (increased) commitment to foreign environments is a central theme of IB literature that seeks to explain how firms internationalize (Johanson \& Vahlne, 1977, 2009, 2017). RBV has little to say about such spatial transaction costs; institutional or cultural barriers to doing business in foreign locations; or experiential learning, which again limits its applicability to IB research. Figure 3 summarizes our understanding of the domain of applicability of RBV relative to other major theoretical perspectives across levels of analysis (MNE, Division, Foreign Subsidiary, Transactions) and key IB research areas (Location Choices, Investment Characteristics, Competitive Capabilities, and Performance Consequences). In the context of large MNEs, which are very often multidivisional, we believe RBV is best suited for capabilities and performance research mainly at the Division (Product/Business Unit) level and to a lesser extent at the foreign subsidiary level.

\footnotetext{
$* * *$ Insert Figure 3 about here $* * *$
} 


\section{Directions for Additional Use of RBV in IB research}

\section{Diversified Corporations}

Many of the large MNEs, including Japanese MNEs which occupy much of my research, are diversified conglomerates. Rather than applying RBV to examine a (diversified) corporation as a whole, we believe (as noted in our level of analysis section above), that a finer-grained, business-unit or product division level perspective is appropriate. The importance of doing so is emphasized in Villasalero's (2017) use of focused product divisions for understanding development and orchestration of resource bases, and corresponding performance. His study analyzes the provider-receiver patterns of knowledge flows among (related) product divisions of large Spanish corporations. Results indicate that product divisions which are strong in knowledge outflow, outperform divisions that are weak, thereby signaling valuable and unique resource endowments that knowledge providing divisions possess.

However, RBV may also be applied to diversified conglomerates which have numerous unrelated business divisions. Lee, Park, Ghauri, and Park (2014) examine the effect of innovative knowledge and its transfer between manufacturing divisions (group companies) such as textiles, petrochemicals, electronics, within large Korean business groups (chaebols); on performance of group company subsidiaries. Results revealed that moderate to high levels of explorative and exploitative knowledge exchanges between group companies and focal subsidiary dependence on knowledge transfer from its group HQ led to improved subsidiary performance.

The above studies used pooled cross sectional data and single-level regression analysis. We call for similar studies that disaggregate large corporations into meaningful units for RBV analysis, combined with the rigor of multi-level, longitudinal modeling approaches (see Hitt, Beamish, Jackson, \& Mathieu, 2007). Pertinent research questions include the following. What 
resources and capabilities from higher organizational levels do foreign subsidiaries draw upon to improve competitive advantage? What knowledge transfer mechanisms between corporate, division, and foreign subsidiary levels lead to superior performance?

\section{Subsidiary Agglomeration}

MNE foreign subsidiaries are often established in close proximity to their home country, business group, and industry (and related) sector businesses. Such co-ethnic and co-industry clusters provide a common ground to address host location challenges, efficiently collaborate, and share knowledge (Chakravarty \& Beamish, 2019; Chung \& Song, 2004; Stallkamp, Pinkham, Schotter, \& Buchel, 2017). Scholars have applied RBV logic to explain cluster based competitive advantages. Enright (2000) suggested that clusters as a group may be considered VRIO due to unique historical conditions, tacit knowledge, social interaction complexity, and long-term evolution. Extending this logic, Tallman, Jenkins, Henry, and Pinch (2004) explained why firms in clusters may as a group outperform non-clustered firms, even while there is performance variation within the cluster. They suggested that some types of knowledge can flow easily between cluster firms, enhancing their joint competitiveness, while other types remain firm-specific and preserve intra-cluster performance differentials.

Research also notes that such agglomeration can have negative consequences. Increased density of firms within a cluster may lead to hyper-competition among firms for resources, insular competitive practices, and reduced innovation (Beaudry \& Swann, 2009; Pouder \& St. John, 1996). Shaver and Flyer (2000) pointed out the risk of negative knowledge spillovers for MNE subsidiaries with the best technologies and human capital. In fact, IB literature has long suggested that these risks make it unlikely for larger, more technically capable and differentiated MNEs to 
cluster with their industry/value-chain peers (Alcácer, 2006; Nachum \& Wymbs, 2005; Shaver \& Flyer, 2000).

However there is also evidence to suggest that the gains from clustering may outweigh the risks for large MNEs. Stallkamp et al.'s (2018) study of co-ethnic agglomerations of Japanese subsidiaries in China indicated that larger MNEs are more likely to be part of co-ethnic clusters in advanced urban areas. Owen-Smith \& Powell (2004) found that larger MNEs are well organized to exploit dual advantages of spatial proximity and global innovation networks. Additionally, there is growing consensus in the strategic management/RBV literature that capability advantages result from combining sets of unique and complementary resources, activities, and assets (Argyres \& Zenger, 2012), which are hard for competitors to replicate. Alvarez and Barney (2001) explain why it is especially difficult for smaller firms to learn about and imitate a larger firm's capabilities, which are diffused across the value chain, while it is much easier for larger firms to understand a smaller firm's technology, which is often embedded in discrete products or processes.

Hence an area for fruitful RBV based research involves clarification of the importance of proximity based advantages (and disadvantages) relative to MNE ownership advantages. Related research questions include the following. What kinds of MNEs gain from locating their foreign subsidiaries in clusters of other MNE subsidiaries and domestic firms? How can they improve their competitive position in the cluster, while minimizing the risk of negative knowledge spillovers? What kinds of capabilities are hard for competitors located in close proximity to replicate?

\section{EMNE Internationalization}

Over the last two decades, the international expansion of emerging market multinational enterprises (EMNEs) has altered the international business (IB) landscape, attracting increased scholarly attention (Luo \& Zhang, 2016). Evidence suggests that EMNEs are expanding their 
international commitment through foreign direct investment at a much faster pace than their advanced market MNE (AMNE) counterparts have done, despite often lacking traditional advantages of technology, brand, and managerial experience (Guillen \& Garcia-Canal, 2012; Mathews, 2006). Of particular interest is that EMNE expansion into advanced economies is often at odds with the Uppsala model's thesis (Johanson \& Vahlne, 1977; 2009) of entering proximate (low geographical and psychic distance) countries first and gradually expanding investment commitment over time.

The springboard perspective (Luo \& Tung, 2007) suggests that EMNEs use international expansion as a launchpad to acquire critical technology and strategic assets in advanced economies. Such acquisitions help overcome resource/capability disadvantages and boost global EMNE competitiveness (Gammeltoft \& Hobdari, 2017; Makino, Lau, \& Yeh, 2002). However, creating value and competitive advantage from these assets requires capabilities to sense acquisition opportunities in the (global) environment; (global) orchestration skills to reconfigure processes and effectively deploy these assets; and learning mechanisms to upgrade these assets; (Rumelt, 2011; Teece, 2014; Teece, Pisano, \& Schuen, 1997). Gammeltoft and Hobdari (2017) argue that (dynamic) capabilities may be perceived not only as a consequence but also as a key antecedent of EMNE strategic asset-seeking investments.

We believe RBV based research can contribute to a better explanation of the rapid internationalization process of emerging market multinational enterprises (EMNEs). A pertinent area for further research entails better understanding EMNE motivations and capabilities for successful acquisition and integration of advanced economy strategic assets. Illustrative research questions include the following. How does learning, cognition, and managerial experience affect EMNE resource-seeking motivations? How do EMNEs determine the viability and cost/benefit of 
such acquisitions? (How) do they possess, obtain, or develop capabilities to integrate acquisitions and realize synergies? How does post-acquisition performance of EMNEs compare to AMNEs?

\section{Subsidiary Autonomy}

We suggest that foreign subsidiary autonomy lends itself well to the application of RBV. A reasonable degree of autonomy (from Corporate or Divisional MNE HQ) can enable subsidiary managers to better respond to external threats and opportunities and address internal resource and capability gaps (Birkinshaw, Hood, \& Young, 2005). Given the disaggregation and complexity of MNE activity across geographies and competitive environments, empowering subsidiary managers to make strategic decisions can help improve alignment with local contexts (Birkinshaw, 1997; Young \& Tavares, 2004). Autonomy facilitates a more meaningful examination of the relationship between subsidiary-level capabilities (and their orchestration) with subsidiary performance.

Much research has studied the antecedents and outcomes of foreign subsidiary autonomy. In terms of antecedents, scholars have examined the effect of subsidiary size (e.g., Johnston \& Menguc, 2007), institutional differences between home and host countries (e.g., Luo, 2003), entry mode (e.g., Slangen \& Hennart, 2008), industry context (e.g., Mudambi \& Navarra, 2004), and HR slack (Verbeke \& Yuan, 2013). Regarding performance outcomes such as innovation, sales growth, and return on assets, a recent meta-analysis of 94 studies across over 23,000 foreign subsidiaries finds an overall positive relationship between autonomy and performance (Geleilate, Andrews, \& Fainshmidt, 2019).

While this is a relatively well researched area, we expect RBV research can contribute further to its development based on two avenues suggested by Geleilate et al. (2010). The first involves equifinal performance configurations. For instance, within the same MNE and industry 
sector, a small advanced economy subsidiary, with a strong marketing capability, and an expatriate manager who is afforded considerable autonomy; could achieve the same level of profitability as a large emerging economy subsidiary with strong customer service capability, and a local manager who is subject to greater HQ control. Even if numerous interaction effects are captured using multiple regressions and/or structural equation models, the principle of 'equifinality' is lost in the process (Kim \& Aguilera, 2016). Hence, this requires using a set theoretic or fuzzy approach (Fiss, 2011) to identify several necessary and sufficient explanatory variable combinations, which result in the same outcome. Second, the degree of subsidiary autonomy can co-evolve over time along with its capabilities and performance. For instance, following establishment, if a subsidiary's performance is strong, HQ may loosen its control and provide the manager with greater decisionmaking autonomy. As the subsidiary grows, its increasing importance to the MNE, greater scope of operations, and interdependence with other subsidiaries may lead to the HQ exerting more control. Related research questions are as follows. What combination of subsidiary autonomy, capabilities and characteristics results in equifinal outcomes? What is the relationship over time between subsidiary autonomy, capabilities, and performance?

\section{International Joint Ventures and Alliances}

RBV literature explains that alliances and joint ventures are motivated by differential and complementary resources between partner firms (Beamish \& Lupton, 2016), wherein resource heterogeneity is sustained over time (Peteraf, 1993). Such collaborations are a useful vehicle for enhancing critical knowledge that firms lack, and which cannot be developed within an acceptable timeframe or cost (Madhok, 1997). For instance, the combination of technology from an advanced country MNE and host country knowledge from a developing country local partner has been a consistent motivation for international joint venture (IJV) formation (Beamish \& Kachra, 2004). 
Further, such cooperative arrangements between firms are usually based on mutually aligned product-market objectives, which confers a degree of operating autonomy. Joint ventures in fact involve the creation of a separate legally distinct organization, jointly owned by its parent firms. Hence, some alliances and JVs are reasonably disaggregated from the operations of their parent firms and work towards realizing a more focused set of objectives that lends itself well to the use of RBV.

There is very limited research on international JVs and alliances in underserved markets such as sub-Saharan Africa, a region which despite receiving foreign aid and possessing valuable natural resources remains economically underdeveloped and home to many of the poorest people in the world (Chrysostome \& Lupton, 2011; Hearn, 2015). A notable exception is Acquaah's (2009) use of an RBV lens to examine the performance of IJVs in Ghana based on generic strategy (i.e., low-cost or differentiation) and MNE country of origin (i.e., advanced or emerging). Given severe institutional voids in such markets, e.g., corruption, weak intellectual property protection, and short-sighted FDI policies; innovative thinking on business models and partnerships is required (Beamish \& Lupton, 2016). For instance, Kim and Kim (2018) suggest that local partners' relationship-specific assets such as status and business connectivity in the local market can improve the odds of IJV survival especially in weaker institutional environments. Webb, Kistruck, Ireland, and Ketchen (2010) propose that in overcoming institutional voids in base of the pyramid (BOP) markets, NGOs that are embedded in these markets through decades of social effort, may serve as effective partners to MNEs - by providing social relationships, knowledge, and legitimacy. According to these authors, in such markets, NGOs that understand local institutions, legitimate modes of operation, and norms and beliefs regarding the utility of products/services, can help MNEs commercialize product-market ideas. 
We call for more RBV based research into IJVs and alliances that can enable MNEs to overcome challenges, and develop and realize opportunities in underserved markets (countries as well as specific sub-national regions within). Suggested research questions include the following. What have we learned from the successes and failures of IJVs and alliances in the emerging economies of Asia, Africa, and Latin America that is applicable to such markets? What resources and capabilities are critical to success (e.g., local leadership, social legitimacy, low cost innovation, technology adaptation)? What kinds of partnerships and governance mechanisms can address capability gaps, reduce risk, and improve the odds of success? What can we learn from the experience of outliers?

\section{Corporate Social Responsibility (CSR)}

Finally, we draw attention to MNE corporate social responsibility (CSR) i.e., the role of MNEs in the well-being of communities they operate in (and affect), and in balancing stakeholder interests. The contribution or lack thereof of MNEs to socio-economic development is an area that has been quite under-investigated in IB literature (see Kolk, 2016 for a detailed discussion). We

note that the RBV has been extended and applied to business sustainability i.e., conducting business operations in a manner that enables firms to meet their current natural resource requirements, without compromising the resource needs of future generations (Hart, 1995; Hart \& Dowell, 2011). Recent work has also used the lens of RBV to examine the relationship between firm-level resource heterogeneity (across governance, information management, systems, and technology) and response to climate change impacts (Backman, Verbeke, \& Schulz, 2017). These scholars used a large sample of FT500 and non FT500 firms across North America and Europe and a large-scale Carbon Disclosure Project (CDP) database. Along these lines, we call for IB research to theoretically frame and empirically examine the resources and capabilities that drive 
effective MNE CSR outcomes. Suggested research questions include the following. Since CSR is implemented at the local (country) level, what is the contribution of MNE-level heterogeneity (e.g., corporate priorities, resources, partnerships) relative to subsidiary-level capabilities (e.g., local leadership, autonomy, partnerships) in successful CSR? Relatedly, what constitutes an effective governance and delegation mechanism/framework (e.g., CSR conceptualization, design, and funding at the MNE level; and development of specific goals, projects, and partnerships at the subsidiary level)? Given that accomplishing results through CSR (e.g., improving community health and education) takes time, what long-term capabilities (e.g., leadership continuity, enduring cross-sector partnerships, sustaining stakeholder relationships) are critical to success?

\section{Use of RBV in my Cases and Teaching Notes}

An important aspect of RBV is its simplicity and focus on firm performance (strategy). Understanding how firm-level (sustained) competitive advantage arises from valuable, rare, inimitable and well-organized (VRIO) resources and capabilities is broadly applicable to teaching Strategy courses across Undergraduate and Graduate levels. Further, case analysis often requires close attention to the idiosyncratic aspects of a company, which aligns well with the RBV's conceptual focus. Use of RBV and the VRIO framework enables students to more critically evaluate and obtain a far greater understanding of a firm's strengths and weaknesses than conventional SWOT analysis does. Hence, I draw upon RBV to a much greater extent in my teaching cases and corresponding instruction materials (teaching notes). Table 2 lists a selection of seven of my teaching cases whose teaching notes utilize the RBV and also provides a summary of the application and relevance of RBV for each of them. Each of these cases describe strategic 
decision dilemmas facing single product or dominant product firms/divisions making the use of RBV extremely relevant.

*** Insert Table 2 about here ***

\section{Conclusion}

As a preeminent theory of strategic management, the resource-based view (RBV) has been very influential in international business (IB). However, its application to large multinational enterprises (MNEs) remains somewhat limited, relative to other theories such as the eclectic paradigm. This is not surprising, since RBV was conceived to explain performance of countrycentric firms with dominant product businesses, rather than to address the broader product-market scope of diversified MNEs. To facilitate increased and more effective use of RBV in IB, we provide research directions in six areas that are of direct and critical relevance to such MNEs. Within each, we point to relevant literature and methods, and provide illustrative research questions. It is our hope that this article will stimulate IB scholars to substantially advance the use of RBV in MNE research and inform/extend resource-based literature accordingly. 


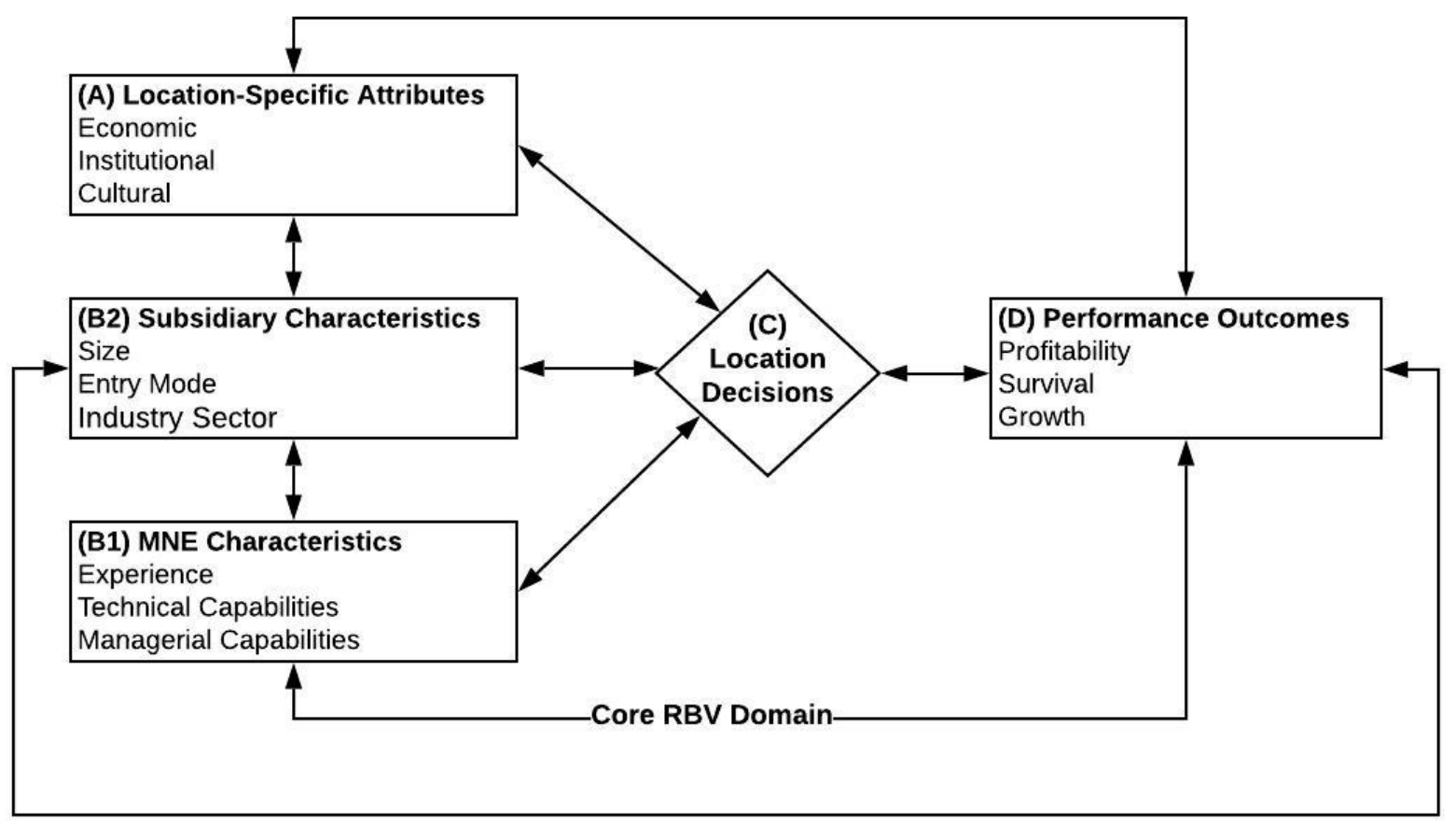

Fig. 1. MNE Location Choice Antecedents, Performance Consequences, and RBV's Core Domain.

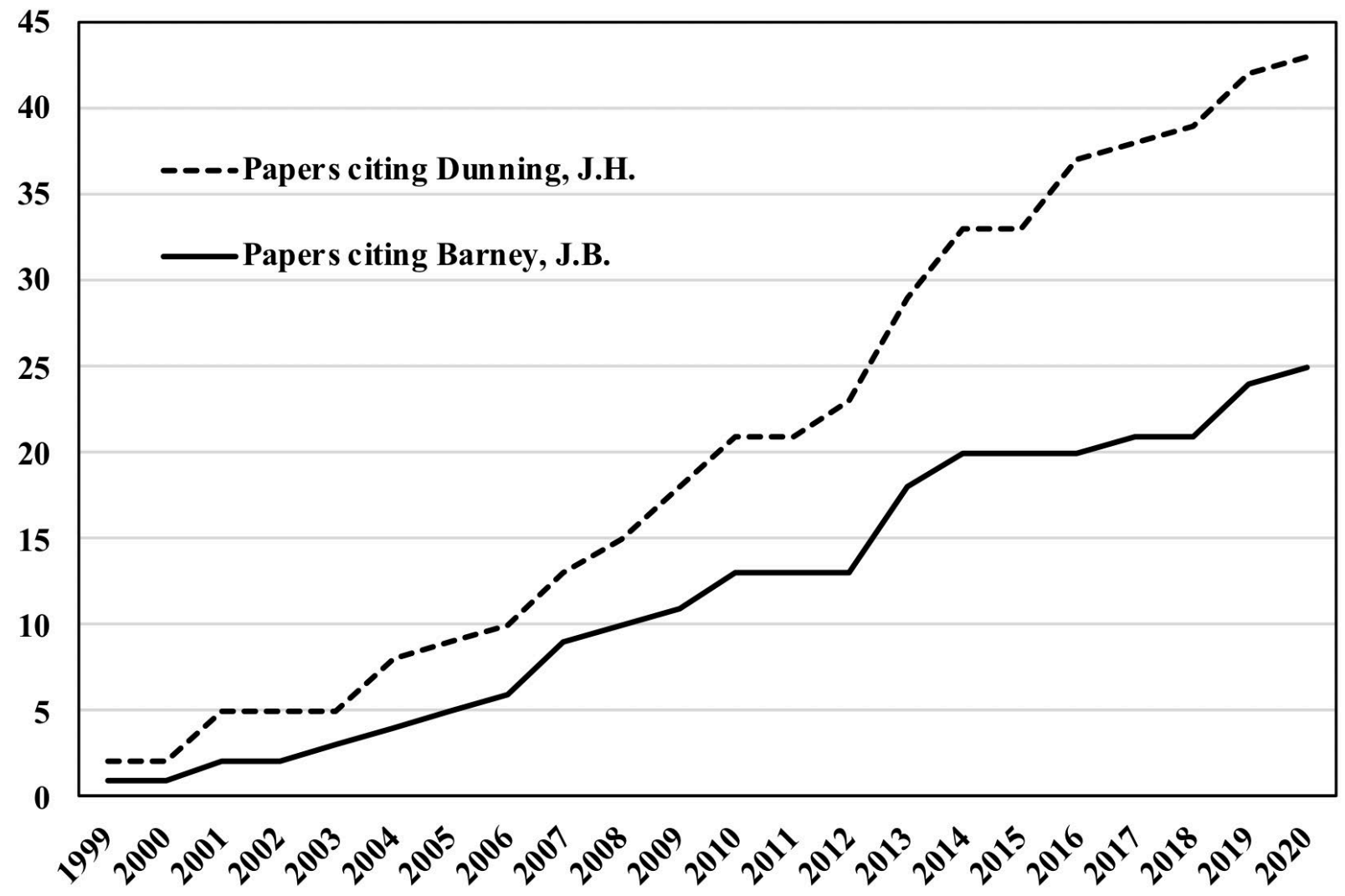

Fig. 2. Beamish articles citing Dunning, J.H. and Barney, J.B. (all journals, cumulative, 1999-2020). Source: Scopus 


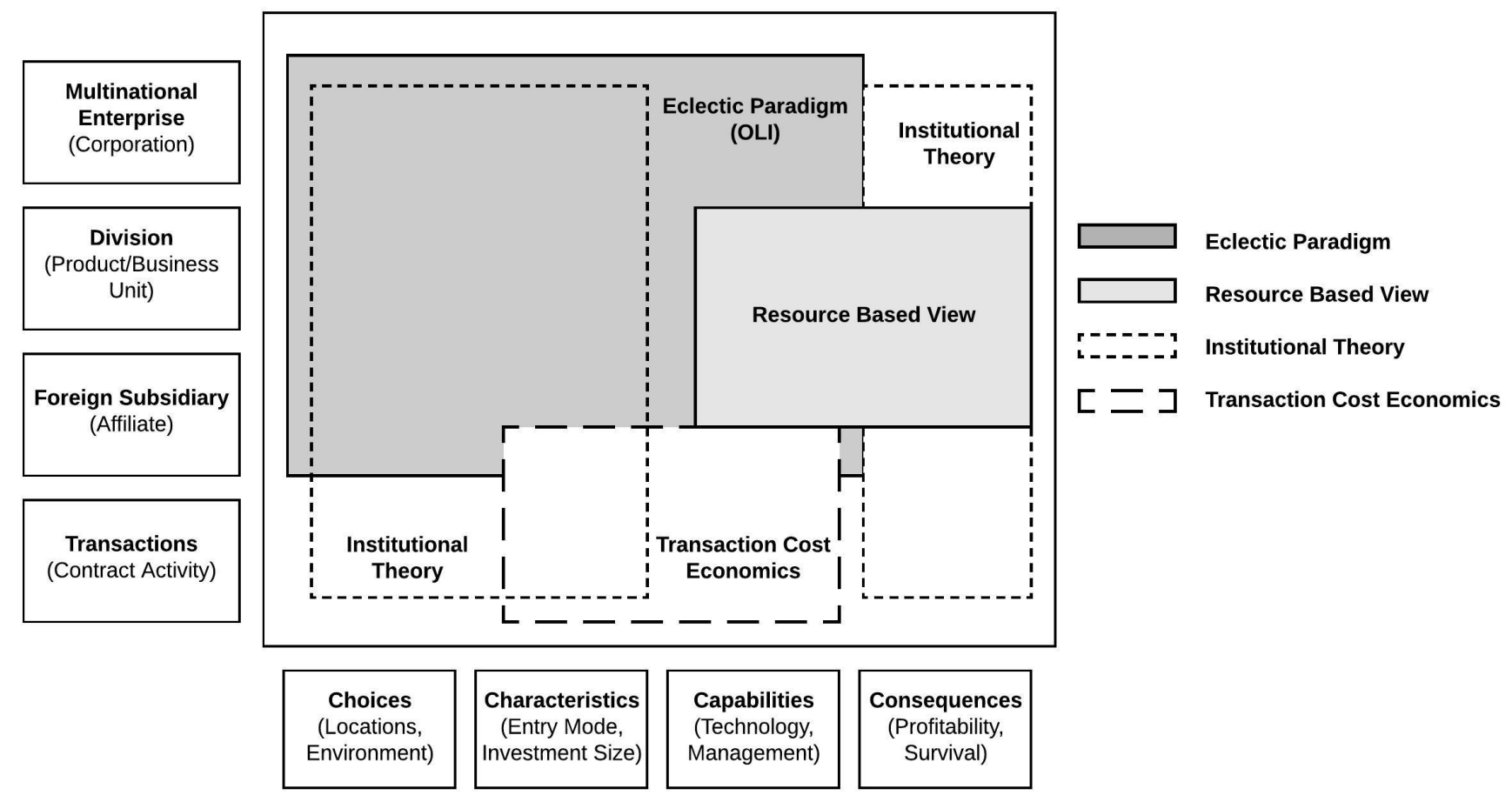

Fig 3. Levels of Analysis, Research Areas, and Theoretical Domains.

Adapted from Doz \& Prahalad, (1991)

\begin{tabular}{|c|l|c}
\hline$\#$ & Author & JIBS citations \\
\hline 1 & Bruce Kogut & 555 \\
\hline 2 & Peter Buckley & 456 \\
\hline 3 & John Dunning & 445 \\
\hline 4 & Geert Hofstede & 408 \\
\hline 5 & Paul Beamish & 380 \\
\hline 6 & Oded Shenkar & 341 \\
\hline 7 & Jan Johanson & 336 \\
\hline 8 & Yadong Luo & 328 \\
\hline 9 & Sri Zaheer & 324 \\
\hline 10 & Alan Rugman & 315 \\
\hline
\end{tabular}

Table 1. Top 10 cited authors in JIBS (excluding editorial citations) from 1991 until September 21, 2020. Source: Scopus 


\begin{tabular}{|c|c|c|c|c|}
\hline$\#$ & Title & Published & Co-author/s & Use of RBV/RBT in Teaching Note \\
\hline 1 & $\begin{array}{l}\text { Domino's Pizza in Japan: } \\
\text { Fortressing or Market } \\
\text { Expansion? }\end{array}$ & (in press)/2021 & $\begin{array}{l}\text { Colette Southam, } \\
\text { Alex Beamish }\end{array}$ & $\begin{array}{l}\text { Delivery speed as competitive advantage, } \\
\text { based on a sophisticated (VRIO) model of } \\
\text { urban store density developed by the center } \\
\text { for global innovation (which harnesses and } \\
\text { transfers best practice across geographies). }\end{array}$ \\
\hline 2 & $\begin{array}{l}\text { Sunton Manufacturing in } \\
\text { Cambodia: Exit or Rem ain }\end{array}$ & $12 / 21 / 2018$ & Zhang feng Fei & $\begin{array}{l}\text { Developing strategy to improve international } \\
\text { competitive advantage (e.g., reduce costs, } \\
\text { enhance design and marketing capabilities). }\end{array}$ \\
\hline 3 & $\begin{array}{l}\text { Crisis at the Bally Wedding } \\
\text { Dress Company }\end{array}$ & $11 / 26 / 2015$ & $\begin{array}{l}\text { Jiqing (Harvey) } \\
\text { Zhu, Lu Yun }\end{array}$ & $\begin{array}{l}\text { Building manufacturing core competencies } \\
\text { in technology and innovation to sustain cost- } \\
\text { based competitive advantage. }\end{array}$ \\
\hline 4 & $\begin{array}{l}\text { IMAX Expansion in BRIC } \\
\text { Economies (Revised) }\end{array}$ & $3 / 16 / 2015$ & $\begin{array}{l}\text { Dwarka } \\
\text { Chakravarty }\end{array}$ & $\begin{array}{l}\text { Identify ing resources and capabilities that } \\
\text { provide international competitive advantage } \\
\text { and assessing VRIO. }\end{array}$ \\
\hline 5 & $\begin{array}{l}\text { Research in Motion: } \\
\text { Managing Explosive } \\
\text { Growth }\end{array}$ & $5 / 15 / 2008$ & $\begin{array}{l}\text { Rod E. White, } \\
\text { Daina Mazutis }\end{array}$ & $\begin{array}{l}\text { Assessing fit between resources and } \\
\text { organizational capabilities given the need to } \\
\text { respond to dynamic environmental } \\
\text { opportunities. }\end{array}$ \\
\hline 6 & Beijing Mirror Corp. & $11 / 25 / 1998$ & $\begin{array}{l}\text { Xiao Yue Chen, } \\
\text { Xin Zhao }\end{array}$ & $\begin{array}{l}\text { Feasibility of Joint Venture to obtain } \\
\text { financial resources, and marketing and } \\
\text { managem ent capabilities required for } \\
\text { international market entry. }\end{array}$ \\
\hline 7 & $\begin{array}{l}\text { Kentucky Fried Chicken in } \\
\text { China (A) }\end{array}$ & $1 / 1 / 1990$ & Allen Morrison & $\begin{array}{l}\text { Understanding that lack of (local) } \\
\text { professional managers is a critical weakness } \\
\text { and developing this capability will require } \\
\text { extensive top managem ent commitment. }\end{array}$ \\
\hline
\end{tabular}

Table 2. Selected Beamish teaching cases that utilize RBV in their teaching notes. 


\section{REFERENCES}

Acquaah, M. (2009). International joint venture partner origin, strategic choice, and performance: A comparative analysis in an emerging economy in Africa. Journal of International Management, 15(1), 46-60.

Ainuddin, R. A., Beamish, P. W., Hulland, J. S., \& Rouse, M. J. (2007). Resource attributes and firm performance in international joint ventures. Journal of World Business, 42(1), 47-60.

Alcácer, J. (2006). Location choices across the value chain: How activity and capability influence collocation. Management Science, 52(10), 1457-1471.

Alvarez, S. A., \& Barney, J. B. (2001). How entrepreneurial firms can benefit from alliances with large partners. Academy of Management Executive, 15(1), 139-148.

Argyres, N. S., \& Zenger, T. R. (2012). Capabilities, transaction costs, and firm boundaries. Organization Science, 23(6), 1643-1657.

Backman, C. A., Verbeke, A., \& Schulz, R. A. (2017). The drivers of corporate climate change strategies and public policy: a new resource-based view perspective. Business \& Society, 56(4), 545-575.

Barney, J. (1991). Firm resources and sustained competitive advantage. Journal of Management, 17(1), 99-120.

Barney J.B. (1997). Gaining and Sustaining Competitive Advantage. Addison-Wesley: Reading, MA.

Barney J.B. \& Mackey T.B. (2005). Testing resource-based theory. In Research Methodology in Strategy and Management, Vol. 2, Ketchen Jr, D.J., \& Bergh D.D. (eds). Elsevier: Greenwich, CT.

Barney, J. B., Ketchen Jr, D. J., \& Wright, M. (2011). The future of resource-based theory: revitalization or decline? Journal of Management, 37(5), 1299-1315.

Beamish, P. W., \& Kachra, A. (2004). Number of partners and JV performance. Journal of World Business, $39(2), 107-120$.

Beamish, P. W., \& Lupton, N. C. (2009). Managing joint ventures. Academy of Management Perspectives, 23(2), 75-94.

Beamish, P. W., \& Lupton, N. C. (2016). Cooperative strategies in international business and management: Reflections on the past 50 years and future directions. Journal of World Business, 51(1), 163-175.

Beaudry, C., \& Swann, G. P. (2009). Firm growth in industrial clusters of the United Kingdom. Small Business Economics, 32(4), 409-424.

Birkinshaw, J. (1997). Entrepreneurship in multinational corporations: The characteristics of subsidiary initiatives. Strategic Management Journal, 18(3), 207-229.

Birkinshaw, J., Hood, N., \& Young, S. (2005). Subsidiary entrepreneurship, internal and external competitive forces, and subsidiary performance. International Business Review, 14(2), 227-248.

Chakravarty, D., \& Beamish, P. (2019). Profitability of foreign direct investment in global cities and co-ethnic clusters. Academy of Management Proceedings, 2019(1), p. 17000.

Choi, C. B., \& Beamish, P. W. (2013). Resource complementarity and international joint venture performance in Korea. Asia Pacific Journal of Management, 30(2), 561-576.

Chrysostome, E. V., \& Lupton, N. C. (2011). Characteristics and performance of Japanese foreign direct investment in Africa. International Journal of Economic Policy in Emerging Economies, 4(1), 54-77.

Chung, W., \& Song, J. (2004). Sequential investment, firm motives, and agglomeration of Japanese electronics firms in the United States. Journal of Economics \& Management Strategy, 13(3), 539-560.

Dai, L., Eden, L., \& Beamish, P. W. (2013). Place, space, and geographical exposure: Foreign subsidiary survival in conflict zones. Journal of International Business Studies, 44(6), 554-578.

Dai, L., Eden, L., \& Beamish, P. W. (2017). Caught in the crossfire: Dimensions of vulnerability and foreign multinationals' exit from war-afflicted countries. Strategic Management Journal, 38(7), 1478-1498

Dhanaraj, C., \& Beamish, P. W. (2003). A resource-based approach to the study of export performance. Journal of Small Business Management, 41(3), 242-261.

Dierickx, I., \& Cool, K. 1989. Asset stock accumulation and sustainability of competitive advantage. Management Science, 35: 1504-1511.

Doz, Y. L., \& Prahalad, C. K. (1991). Managing DMNCs: A search for a new paradigm. Strategic Management Journal, 12(S1), 145-164.

Dunning, J.H. (1995). Reappraising the eclectic paradigm in an age of alliance capitalism. Journal of International Business Studies, 26(3), 461-491. 
Dunning, J. H. (1988). The eclectic paradigm of international production: A restatement and some possible extensions. Journal of International Business Studies, 19(1), 1-31.

Dunning, J. H. (1998). Location and the multinational enterprise: a neglected factor?. Journal of International Business Studies, 29(1), 45-66.

Dunning, J. H., \& Lundan, S. M. (2008). Institutions and the OLI paradigm of the multinational enterprise. Asia Pacific Journal of Management, 25(4), 573-593.

Dutta, D. K., \& Beamish, P. W. (2013). Expatriate managers, product relatedness, and IJV performance: A resource and knowledge-based perspective. Journal of International Management, 19(2), 152-162.

Eden, L., \& Dai, L. (2010). Rethinking the O in Dunning's OLI/eclectic paradigm. Multinational Business Review, 18(1), 13-34.

Enright, M. J. (2000). Regional clusters and multinational enterprises: independence, dependence, or interdependence?. International Studies of Management \& Organization, 30(2), 114-138.

Fang, Y., Wade, M., Delios, A., \& Beamish, P. W. (2007). International diversification, subsidiary performance, and the mobility of knowledge resources. Strategic Management Journal, 28(10), 10531064.

Fiss, P. C. (2011). Building better causal theories: A fuzzy set approach to typologies in organization research. Academy of Management Journal, 54(2), 393-420.

Geleilate, J. M. G., Andrews, D. S., \& Fainshmidt, S. (2019). Subsidiary autonomy and subsidiary performance: A meta-analysis. Journal of World Business, 55(4). https://doi.org/10.1016/j.jwb.2019.101049

Gammeltoft, P., \& Hobdari, B. (2017). Emerging market multinationals, international knowledge flows and innovation. International Journal of Technology Management, 74(1-4), 1-22.

Gaur, A. S., Delios, A., \& Singh, K. (2007). Institutional environments, staffing strategies, and subsidiary performance. Journal of Management, 33(4), 611-636.

Grant, R. M. (1996). Toward a knowledge-based theory of the firm. Strategic Management Journal, 17(S2), 109-122.

Guillén, M. F., \& García-Canal, E. (2012). Emerging markets rule: Growth strategies of the new global giants. NewYork: McGraw Hill.

Hart, S. L. (1995). A natural-resource-based view of the firm. Academy of Management Review, 20(4), 9861014.

Hart, S. L., \& Dowell, G. (2011). Invited editorial: A natural-resource-based view of the firm: fifteen years after. Journal of Management, 37(5), 1464-1479.

Hearn, B. (2015). Institutional influences on board composition of international joint venture firms listing on emerging stock exchanges: Evidence from Africa. Journal of World Business, 50(1), 205-219.

Hennart, J. F. (2009). Down with MNE centric theories! Market entry and expansion as the bundling of MNE and local assets. Journal of International Business Studies, 40(9), 1432-1454.

Hitt, M. A., Beamish, P. W., Jackson, S. E., \& Mathieu, J. E. (2007). Building theoretical and empirical bridges across levels: Multilevel research in management. Academy of Management Journal, 50(6), 1385-1399.

Hymer, S. (1976). The International Operations of National Firms, MIT Press: Cambridge, MA.

Jiang, R. J., Beamish, P. W., \& Makino, S. (2014). Time compression diseconomies in foreign expansion. Journal of World Business, 49(1), 114-121.

Johanson, J., \& Vahlne, J. E. (1977). The internationalization process of the firm-a model of knowledge development and increasing foreign market commitments. Journal of International Business Studies, 8(1), 23-32.

Johanson, J., \& Vahlne, J. E. (2009). The Uppsala internationalization process model revisited: From liability of foreignness to liability of outsidership. Journal of International Business Studies, 40(9), 1411-1431.

Johnston, S., \& Menguc, B. (2007). Subsidiary size and the level of subsidiary autonomy in multinational corporations: A quadratic model investigation of Australian subsidiaries. Journal of International Business Studies, 38(5), 787-801.

Khanna, T., \& Palepu, K. (2000). The future of business groups in emerging markets: Long-run evidence from Chile. Academy of Management Journal, 43 (3), 268-285. 
Kim, J., \& Kim, K. (2018). How does local partners network embeddedness affect international joint venture survival in different subnational contexts? Asia Pacific Journal of Management, 35(4), 1055-1080.

Kim, J. U., \& Aguilera, R. V. (2016). Foreign location choice: Review and extensions. International Journal of Management Reviews, 18(2), 133-159.

Kogut, B. (1997). The evolutionary theory of the multinational corporation. In: B. Toyne \& D. Nigh (eds.), International business: An emerging vision (pp. 470-488). Columbia, SC: University of South Carolina Press.

Kolk, A. (2016). The social responsibility of international business: From ethics and the environment to CSR and sustainable development. Journal of World Business, 51(1), 23-34.

Lee, S. H., Beamish, P. W., Lee, H. U., \& Park, J. H. (2009). Strategic choice during economic crisis: Domestic market position, organizational capabilities and export flexibility. Journal of World Business, 44(1), 1-15.

Lee, J. Y., Park, Y. R., Ghauri, P. N., \& Park, B. I. (2014). Innovative knowledge transfer patterns of groupaffiliated companies: The effects on the performance of foreign subsidiaries. Journal of International Management, 20(2), 107-123.

Lu, J. W., \& Beamish, P. W. (2006). Partnering strategies and performance of SMEs' international joint ventures. Journal of Business Venturing, 21(4), 461-486.

Luo, Y. (2003). Market-seeking MNEs in an emerging market: How parent-subsidiary links shape overseas success. Journal of International Business Studies, 34(3), 290-309.

Luo, Y., \& Tung, R. L. (2018). A general theory of springboard MNEs. Journal of International Business Studies, 49(2), 129-152.

Luo, Y., \& Zhang, H. (2016). Emerging market MNEs: Qualitative review and theoretical directions. Journal of International Management, 22(4), 333-350.

Makino, S., Lau, C. M., \& Yeh, R. S. (2002). Asset-exploitation versus asset-seeking: Implications for location choice of foreign direct investment from newly industrialized economies. Journal of International Business Studies, 33(3), 403-421.

Mathews, J. A. (2006). Dragon multinationals: New players in 21 st century globalization. Asia Pacific Journal of Management, 23(1), 5-27.

Mudambi, R., \& Navarra, P. (2004). Divisional power, intra-firm bargaining and rent-seeking behavior in multidivisional corporations. Economics Bulletin, 4(13), 1-10.

Mudambi, R., \& Puck, J. (2016). A global value chain analysis of the 'regional strategy' perspective. Journal of Management Studies, 53(6), 1076-1093.

Nachum, L., \& Wymbs, C. (2005). Product differentiation, external economies and MNE location choices: M\&As in global cities. Journal of International Business Studies, 36(4), 415-434.

Newbert, S. L. (2007). Empirical research on the resource-based view of the firm: an assessment and suggestions for future research. Strategic Management Journal, 28(2), 121-146.

Nielsen, B. B., Asmussen, C. G., \& Weatherall, C. D. (2017). The location choice of foreign direct investments: Empirical evidence and methodological challenges. Journal of World Business, 52(1), 62-82.

North, D. (1990). C.(1991). Institutions. Journal of Economic Perspectives, 5(1), 97-112.

Owen-Smith, J., \& Powell, W. W. (2004). Knowledge networks as channels and conduits: The effects of spillovers in the Boston biotechnology community. Organization Science, 15(1), 5-21.

Penrose, E. (1959). The theory of the growth of the firm. New York: Wiley.

Peteraf, M. A., \& Barney, J. B. (2003). Unraveling the resource-based tangle. Managerial and Decision Economics, 24(4), 309-323.

Pouder, R., \& St. John, C. H. (1996). Hot spots and blind spots: Geographical clusters of firms and innovation. Academy of Management Review, 21(4), 1192-1225.

Prahalad, C. H., \& Hamel, G. (1990). The Core Competence of the Corporation. Harvard Business Review, 68(3), 295-336.

Rugman, A. M. (1981). Inside the multinationals: The economics of internal markets. New York: Columbia Press.

Rugman, A. M., Verbeke, A., \& Nguyen, Q. T. (2011). Fifty years of international business theory and beyond. Management International Review, 51(6), 755-786.

Rumelt, R. P. (1991). How much does industry matter? Strategic Management Journal, 12(3), 167-185. 
Rumelt, R. (2011). The perils of bad strategy. McKinsey Quarterly, 1(3), 1-10.

Rumelt, R., Schendel, D., \& Teece, D. (eds.) (1994). Fundamental issues in strategy. Boston: HBS Press.

Scott, W. R. (2008). Institutions and organizations: Ideas and interests (3rd ed.). Thousand Oaks, CA: Sage.

Shaver, J., \& Flyer, F. (2000). Agglomeration economies, firm heterogeneity, and foreign direct investment in the United States. Strategic Management Journal, 21(12), 1175-1193.

Slangen, A. H., \& Hennart, J. F. (2008). Do multinationals really prefer to enter culturally distant countries through greenfields rather than through acquisitions? The role of parent experience and subsidiary autonomy. Journal of International Business Studies, 39(3), 472-490.

Stallkamp, M., Pinkham, B. C., Schotter, A. P., \& Buchel, O. (2018). Core or periphery? The effects of countryof-origin agglomerations on the within-country expansion of MNEs. Journal of International Business Studies, 49(8), 942-966.

Tallman, S., Jenkins, M., Henry, N., \& Pinch, S. (2004). Knowledge, clusters, and competitive advantage. Academy of Management Review, 29(2), 258-271.

Teece, D. J., Pisano, G., \& Shuen, A. (1997). Dynamic capabilities and strategic management. Strategic Management Journal, 18(7), 509-533.

Teece, D. J. (2014). The foundations of enterprise performance: Dynamic and ordinary capabilities in an (economic) theory of firms. Academy of Management Perspectives, 28(4), 328-352.

Vahlne, J. E., \& Johanson, J. (2017). From internationalization to evolution: The Uppsala model at 40 years. Journal of International Business Studies, 48(9), 1087-1102.

Verbeke, A., \& Yuan, W. (2013). The Drivers of Multinational Enterprise Subsidiary Entrepreneurship in China: A New Resource-Based View Perspective. Journal of Management Studies, 50(2), 236-258.

Vermeulen, F., \& Barkema, H. (2001). Learning through acquisitions. Academy of Management Journal, 44(3), 457-476.

Villasalero, M. (2017). A resource-based analysis of realized knowledge relatedness in diversified firms. Journal of Business Research, 71, 114-124.

Webb, J. W., Kistruck, G. M., Ireland, R. D., \& Ketchen Jr, D. J. (2010). The entrepreneurship process in base of the pyramid markets: The case of multinational enterprise/nongovernment organization alliances. Entrepreneurship Theory and Practice, 34(3), 555-581.

Wernerfelt, B. (1984). A resource-based view of the firm. Strategic Management Journal, 5(2) 171-180.

Young, S., \& Tavares, A. T. (2004). Centralization and autonomy: back to the future. International Business Review, 13(2), 215-237.

Zaheer, S. (1995). Overcoming the liability of foreignness. Academy of Management Journal, 38(2), 341-363. 